\title{
PERTANGGUNGJAWABAN KEPALA DESA KARANG TUNGGAL KECAMATAN TENGGARONG SEBERANG KABUPATEN KUTAI KARTANEGARA DALAM HAL PENGELOLAAN KEUANGAN DAN ASET DESA (DITINJAU DARI UNDANG-UNDANG REPUBLIK INDONESIA NOMOR 6 TAHUN 2014 TENTANG DESA)
}

\author{
Andreas Hary Susanto Marbun dan Dinny Wirawan Pratiwie \\ Marbuna052@gmail.com,dinnipratiwie@uwgm.ac.id \\ Fakultas Hukum Universitas Widya Gama Mahakam Samarinda
}

\begin{abstract}
ABSTRAK
Negara Kesatuan Repulik Indonesia dalam menyelenggarakan sistem pemerintahan menganut asas Desentralisasi dengan memberikan kesempatan dan keleluasan kepada daerah untuk menyelenggarakan Otonomi Daerah. Indonesia merupakan sebuah kesatuan wilayah yang terdiri dari pemerintahan pusat dan pemerintahan daerah, sebagaimana diatur dalam ketentuan Pasal 18 ayat (1) Undang-Undang Dasar 1945 yang menyebutkan bahwa Negara Kesatuan Republik Indonesia dibagi atas daerah-daerah provinsi dan daerah provinsi itu dibagi atas kabupaten dan kota, yang tiap-tiap provinsi, kabupaten, dan kota itu mempunyai pemerintahan daerah, yang diatur dengan undang-undang. Pemerintahan daerah Kabupaten/ Kota terdiri dari wilayah kecamatan, dan setiap kecamatan memilki kelurahan/ desa didalamnya, wajah baru desa menjadi harapan mengiringi pembentukan Undang-Undang Nomor 6 Tahun 2014 tentang Desa yang menjadi titik awal harapan desa untuk bisa menentukan posisi, peran dan kewenangan atas dirinya supaya desa bisa bertenaga secara sosial dan berdaulat secara politik sebagai fondasi demokrasi desa, serta berdaya secara ekonomi dan bermartabat secara budaya sebagai wajah kemandirian desa dan pembangunan desa. Pada Pasal 26 telah memberikan kesempatan Kepala Desa untuk mengelola keuangan dan aset yang dimiliki desa. Tahapan pengelolaan keuangan desa tersebut telah diatur dengan Peraturan Menteri Dalam Negeri Republik Indonesia Nomor 113 Tahun 2014 Tentang Pengelolaan Keuangan Desa, dan Peraturan Menteri Dalam Negeri Republik Indonesia Nomor 1 Tahun 2016 Tentang Pengelolaan Aset Desa mengatur tata cara pengelolaan aset desa. Pengelolaan keuangan dan aset desa tidak lepas dari kemampuan Kepala Desa dan perangkat desa lainnya. Pertanggungjawaban Kepala Desa dalam hal mengelola keuangan dan aset desa secara baik, benar, transparan dan sesuai dengan peraturan perundang-undangan yang berlaku sangat diperlukan untuk memajukan pembangunan dan perekonomian di desa, termasuk desa Karang Tunggal sebagai salah satu pemerintahan yang berada dibawah Pemerintahan Kabupaten Kutai Kartanegara.
\end{abstract}

Kata Kunci: Pertanggungjawaban, Kepala Desa, Pengelolaan, Keuangan Desa, Aset Desa. 


\begin{abstract}
The Unitary Republic of Indonesia's Republic of Indonesia in organizing the system of government embraces the principle of Decentralization by providing opportunities and freedom to the regions to organize Regional Autonomy. Indonesia is a regional entity consisting of central government and local government, as regulated in the provisions of Article 18 paragraph (1) of the 1945 Constitution which states that the Unitary State of the Republic of Indonesia is divided into provinces and provinces are divided into districts and city, where each province, district, and city have local government, which is regulated by law. The district / municipality government comprises the subdistrict area, and each sub-district has village / village in it, the village's new face becomes the hope of accompanying the establishment of Law No. 6 of 2014 on the Village which becomes the starting point of the village's hope to be able to determine the position, role and authority over himself so that the village can be politically and politically swayed as the foundation of village democracy, as well as economically and culturally dignified as the face of village self-reliance and rural development. Article 26 has given the village chief the opportunity to manage the finances and assets owned by the village. The stages of the village financial management have been regulated by the Minister of Home Affairs Regulation No. 113 of 2014 on Village Financial Management, and the Regulation of the Minister of Home Affairs of the Republic of Indonesia No. 1 of 2016 on Village Asset Management regulates the procedures for managing village assets. The management of village finances and assets can't be separated from the ability of the Village Head and other village apparatus. The responsibility of the Village Head in managing village finances and assets properly, transparently and in accordance with applicable laws and regulations is necessary to promote the development and economy of the village, including Karang Tunggal village as one of government under Kutai Kartanegara.
\end{abstract}

Keywords: Accountability, Village Head, Management, Village Finance, Village Assets.

\title{
PENDAHULUAN
}

\section{A. Latar Belakang Masalah}

Negara Kesatuan Repulik Indonesia dalam menyelenggarakan sistem pemerintahan menganut asas Desentralisasi dengan memberikan kesempatan dan keleluasan kepada daerah untuk menyelenggarakan Otonomi Daerah. Indonesia merupakan sebuah kesatuan wilayah yang terdiri dari pemerintahan pusat dan pemerintahan daerah, sebagaimana diatur dalam ketentuan Pasal 18 ayat (1) Undang-Undang Dasar 1945 yang menyebutkan bahwa Negara Kesatuan Republik Indonesia dibagi atas daerahdaerah provinsi dan daerah provinsi itu dibagi atas kabupaten dan kota, yang tiap-tiap provinsi, kabupaten, dan kota itu mempunyai pemerintahan daerah, yang diatur dengan undang-undang. Daerahdaerah yang bersifat otonomi diberi kewenangan untuk mengurus dan menjalankan otonomi seluas-luasnya berdasarkan keinginan dan kebutuhan masyarakat di daerah, melalui pemerintahan daerah kecuali urusan pemerintah yang oleh Undang-Undang ditentukan sebagai urusan Pemerintah Pusat.

Otonomi daerah tumbuh karena adanya beberapa tuntutan dari berbagai pihak mampu untuk mengubah sistem pemerintahan yang ada sebelumnya. Desa 
sebagai pemerintahan yang langsung bersentuhan dengan masyarakat menjadi fokus utama dalam pembangunan pemerintah, hal ini dikarenakan sebagian besar wilayah Indonesia ada di perdesaan. Berdasarkan Undang-Undang Nomor 6 Tahun 2014 tentang Desa menyatakan penatausahaan keuangan pemerintah desa terpisah dari keuangan pemerintah kabupaten. Desa memerlukan posisi yang sangat strategis, sehingga diperlukan adanya Perhatian yang serimbang terhadap penyelenggaraan otonomi daerah. ${ }^{1}$

Pemerintahan daerah Kabupaten/ Kota terdiri dari wilayah kecamatan, dan setiap kecamatan memilki kelurahan/ desa didalamnya, Pemerintahan yang berada dibawah Pemerintahan Daerah Kabupaten/ Kota sendiri adalah Pemerintahan Desa, wajah baru desa menjadi harapan mengiringi pembentukan Undang-Undang Nomor 6 Tahun 2014 tentang Desa dengan posisi, peran dan kewenangan desa yang baru sebagai sektor pemerintahan yang paling bawah dalam sistem pemerintahan Negara Kesatuan Republik Indonesia.

Terbitnya Undang-Undang Nomor 6 Tahun 2014 tentang Desa, yang selanjutnya disebut dengan UU Desa, menjadi sebuah titik awal harapan desa untuk bisa menentukan posisi, peran dan kewenangan atas dirinya. Harapan supaya desa bisa bertenaga secara sosial dan berdaulat secara politik sebagai fondasi demokrasi desa, serta berdaya secara ekonomi dan bermartabat secara budaya sebagai wajah kemandirian desa dan pembangunan desa. Harapan tersebut semakin menggairah ketika muncul

${ }^{1}$ Dewi Risnawati, Pengelolaan Aset Desa Dalam Upaya Meningkatkan Kesejahteraan Di Desa Krayan Bahagia Kecamatan Long Ikis Kabupaten Paser, e-Journal Ilmu Pemerintahan, Volume 5, Nomor 1, 2017: 199-212, hal. 200.

${ }^{2}$ M. Silahuddin, Kewenangan Desa Dan Regulasi Desa, Kementerian Desa, Pembangunan Daerah Tertinggal, dan kombinasi antara asas rekognisi dan subsidiaritas sebagai asas utama yang menjadi ruh Undang-Undang ini. $^{2}$

Pembangunan desa bertujuan meningkatkan kesejahteraan masyarakat desa dan kualitas hidup manusia serta penanggulangan kemiskinan melalui penyediaan pemenuhan kebutuhan dasar, pembangunan sarana dan prasarana, pengembangan potensi ekonomi lokal, serta pemanfaatan sumber daya alam dan lingkungan secara berkelanjutan.

Desa sebagaimana pada konstitusi sebelumnya menggunakan norma yang ada dalam Undang-Undang Republik Indonesia Nomor 5 tahun 1979 tentang Pemerintahan Desa dan Undang-Undang Republik Indonesia Nomor 32 tahun 2004 tentang Pemerintahan Daerah adalah struktur pemerintahan terendah dibawah kabupaten. Desa menerima tugas perbantuan dari pemerintah, pemerintah provinsi, pemerintah kabupaten/ kota. Sebagai organisasi pemerintahan yang berada dalam sistem pemerintahan kabupaten/ kota maka kedudukan desa sebagai local state government. ${ }^{3}$

Sistem pengelolaan pemerintahan desa sebagaimana yang dijelaskan diatas, desa tak lebih hanya sekedar menjadi kepanjangan tangan dari pemerintah kabupaten/ kota, pemerintah provinsi maupun pemerintah pusat. Pemerintah desa lebih banyak hanya bertugas sebagai pelaksana pembangunan yang telah didesain oleh pemerintah diatasnya. Mengerjakan proyek yang direncanakan meskipun seringkali kurang bermanfaat bagi

Transmigrasi Republik Indonesia, Jakarta Pusat, Cet. I Maret 2015, hal. 8.

${ }^{3}$ Mochammad Zaini Mustakim, Kepemimpinan Desa, Kementerian Desa, Pembangunan Daerah Tertinggal, dan Transmigrasi Republik Indonesia, Jakarta Pusat, Cet. I Maret 2015, hal. 9. 
masyarakat Desa. Sekarang ini regulasi tentang desa telah diatur khusus, terbitnya Undang-Undang Republik Indonesia Nomor 6 tahun 2014 tentang Desa menegaskan desa bukan lagi local state goverment tapi Desa sebagai pemerintahan masyarakat, hybrid antara self governing community dan local self government. ${ }^{4}$ Desa dalam UU Desa telah hadir dengan asas atau prinsip umum Rekognisi-subsidiaritas. Rekognisi merupakan pengakuan dan penghormatan terhadap Desa, sesuai dengan amanat Undang-Undang Dasar 1945 Pasal 18 B ayat 2 yang memberikan pengakuan dan penghormatan terhadap kesatuan masyarakat hukum adat beserta hak-hak tradisionalnya. Dengan dua azas utama "rekognisi" dan "subdidiaritas" UU Desa mempunyai semangat revolusioner, berbeda dengan azas "desentralisasi" dan "residualitas". Dengan mendasarkan pada azas desentralisasi dan residualitas, desa hanya menjadi bagian dari daerah, sebab desentralisasi hanya berhenti di kabupaten/ kota. Disamping itu, desa hanya menerima pelimpahan sebagian kewenangan dari kabupaten/ kota. Sehingga desa hanya menerima sisa-sisa lebihan daerah, baik sisa kewenangan maupun sisa keuangan dalam bentuk Alokasi Dana Desa. ${ }^{5}$

Pedesaan merupakan bagian integral dari Negara Kesatuan Republik Indonesia, membangun desa berarti membangun sebagian besar penduduk Indonesia, hal ini mudah dimengerti karena lebih dari delapan puluh persen penduduk Indonesia tersebar di desa-desa seluruh Indonesia. Desa sebagai pemerintahan yang langsung bersentuhan dengan masyarakat menjadi fokus utama dalam pembangunan pemerintah, hal ini dikarenakan sebagian besar wilayah Indonesia ada di perdesaan. UU Desa menyatakan penatausahaan keuangan pemerintah desa terpisah dari keuangan pemerintah kabupaten/ kota. Pengelolaan keuangan desa tidak lepas dari Kepala Desa dan perangkat desa lainnya. Kemampuan desa untuk mengelola pembangunan lebih mandiri yang didukung oleh semua unsur dan sumber daya desa sangat penting bagi perbaikan kesejahteraan masyarakat, terlebih bagi masyarakat miskin di desa. Desa yang dapat menjalankan pengelolaan pembangunan secara mandiri bukan hanya mampu menggerakkan seluruh aset sumber daya yang dimiliki desa, tetapi desa juga akan mampu memperbaiki kebutuhan dasar warga, kebutuhan penghidupan, memperjuangkan hak warga dan menata kehidupan secara berkelanjutan.

Pada masa sekarang ini, peranan pemerintahan desa sangatlah penting dalam perkembagan sistem administrasi di Indonesia, bahwa dalam perjalanan ketatanegaraan Republik Indonesia, desa telah berkembang dalam berbagai bentuk sehingga perlu dilindungi dan diberdayakan agar menjadi kuat, maju, mandiri, dan demokratis, untuk dapat menciptakan landasan yang kuat dalam melaksanakan pemerintahan dan pembangunan menuju masyarakat yang adil, makmur, dan sejahtera. Pembentukan UU Desa tersebut, membuka ruang bagi pemerintah desa untuk membuat atau menentukan kebijakan untuk memajukan desa, salah satu kebijakan yang dapat dilakukan pemerintah desa misalnya dalam hal mengelola keuangan dan aset desa.

Pertanggungjawaban Kepala Desa dalam mengelola keuangan dan aset desa secara baik, benar dan transparan sangat diperlukan untuk memajukan pembangunan dan perekonomian di desa sebagai salah satu pemerintahan yang berada dibawah Pemerintahan Kabupaten/Kota. Secara khusus Kabupaten Kutai Kartanegara memiliki desa-desa yang termasuk memiliki 
kewenangan dalam pengelolaan keuangan dan aset desa, Kabupaten Kutai Kartanegara terdiri dari 18 wilayah kecamatan dan 225 desa/ kelurahan, salah satunya adalah Kecamatan Tenggarong Seberang yang memiliki 18 desa, salah satunya desa Karang Tunggal, pembangunan didesa Karang Tunggal ini termasuk desa yang memiliki kemajuan pembangunan yang cukup pesat dan memiliki potensi-potensi yang dapat meningkatkan kemajuan desa yang perlu dikelola dan diberdayagunakan oleh pemerintahan desa.

\section{B. Rumusan Masalah}

Adapun perumusan masalah dalam penelitian ini antara lain :

1. Bagaimana pertanggungjawaban Kepala Desa Karang Tunggal Kecamatan Tenggarong Seberang Kabupaten Kutai Kartanegara dalam hal pengelolaan keuangan dan aset desa ditinjau dari Undang-Undang Republik Indonesia Nomor 6 Tahun 2014 tentang Desa?

2. Apa yang menjadi kendala-kendala pertanggungjawaban Kepala Desa Karang Tunggal dalam hal pengelolaan keuangan dan aset desa di Desa Karang Tunggal Kecamatan Tenggarong Seberang Kabupaten Kutai Kartanegara?

\section{Tujuan dan Manfaat Penelitian}

Adapun Tujuan Penelitian ini untuk Pertanggungjawaban Kepala Desa Karang Tunggal dalam hal Pengelolaan Keuangan dan Aset Desa di Desa Karang Tunggal, Kecamatan Tenggarong Seberang, Kabupaten Kutai Kartanegara. Dan Kendala apa saja dalam Pertanggungjawaban Kepala Desa Karang Tunggal dalam Pengelolaan Keuangan dan Aset Desa di Kecamatan Ternggarong Sebrang Kabupaten Kutai Kartanegara.
Penelitian ini diharapkan mampu memberikan manfaat baik secara teoritis yaitu dapat memberikan sumbangan pemikiran pada perkembangan ilmu hukum secara umum, serta ilmu pengetahuan di bidang hukum khususnya dalam ilmu Hukum Administrasi Negara yang berkaitan dengan obyek penelitian, yaitu mengenai pertanggungjawaban Kepala Desa dalam hal pengelolaan keuangan dan aset desa. Dan secara Praktis diharapkan Sebagai bahan informasi kepada masyarakat khususnya kepada masyarakat di Desa Karang Tunggal Kecamatan Tenggarong Seberang Kab. Kutai Kartanegara mengenai pertanggungjawaban Kepala Desa dalam hal pengelolaan keuangan dan aset desa.

\section{METODE PENELITIAN}

\section{A. Jenis Penelitian dan Sumber Data}

Metode penelitian yang digunakan adalah metode yuridis normatif, dengan menggunakan sumber hukum bahan primer, berupa Undang Undang Dasar 1945 Amandemen IV, Undang-Undang Republik Indonesia Nomor 6 Tahun 2014 Tentang Desa, Lembaran Negara Republik Indonesia Tahun 2014 Nomor 7, Tambahan Lembaran Negara Republik Indonesia Nomor 5495, Peraturan Pemerintah Republik Indonesia Nomor 43 Tahun 2014 Tentang Peraturan Pelaksanaan Undang-Undang Nomor 6 Tahun 2014 Tentang Desa, Lembaran Negara Republik Indonesia Tahun 2014 Nomor 123, Tambahan Lembaran Negara Republik Indonesia Nomor 5539, Peraturan Pemerintah Republik Indonesia Nomor 47 Tahun 2015 Tentang Perubahan Atas Peraturan Pemerintah Nomor 43 Tahun 2014 Tentang Peraturan Pelaksanaan Undang-Undang Nomor 6 Tahun 2014 Tentang Desa, Lembaran Negara Republik Indonesia Tahun 2015 Nomor 157, Tambahan Lembaran Negara Republik Indonesia Nomor 5717, Peraturan Menteri 
Dalam Negeri Republik Indonesia Nomor 4 Tahun 2007 tentang Pedoman Pengelolaan Kekayaan Desa, Peraturan Menteri Dalam Negeri Republik Indonesia Nomor 113 Tahun 2014 Tentang Pengelolaan Keuangan Desa, Berita Negara Republik Indonesia Tahun 2014 Nomor 2093, Peraturan Menteri Dalam Negeri Republik Indonesia Nomor 1 Tahun 2016 Tentang Pengelolaan Aset Desa, Berita Negara Republik Indonesia Tahun 2016 Nomor 53.

Adapun bahan sekunder dalam penelitian ini adalah data pendukung atau penunjang pembahasan daripada permasalahan yang akan diteliti, bahan hukum sekunder yang terutama adalah buku-buku hukum termasuk Skripsi, tesis, dan disertasi hukum serta jurnal-jurnal hukum ${ }^{6}$, Bahan hukum sekunder yang digunakan untuk membantu memahami berbagai konsep hukum dalam bahan hukum primer, analisis bahan hukum primer dibantu oleh bahan hukum sekunder yang diperoleh dari berbagai sumber baik jurnal, bukubuku, serta karya ilmiah lainnya yang terkait dengan permasalahan yang diangkat.

Penelitian ini juga menggunakan bahan hukum tersier yaitu bahan yang memberikan petunjuk maupun penjelasan terhadap bahan hukum primer dan bahan hukum sekunder, seperti kamus (hukum), ensiklopedia. ${ }^{7}$ Bahan hukum tersier yang digunakan berupaka internet yang berhubungan dengan permasalahan yang menjadi objek penelitian dalam penelitian ini.

\section{B. Teknik Pengumpulan Data}

Teknik pengumpulan data yang akan digunakan dalam penelitian ini berupak Studi Kepustakaan (Bibliograophy study) yaitu dengan mengkaji buku-buku yang relevan dengan permasalahan yang penulis

${ }^{6}$ Peter Mahmud Marzuki, Penelitian Hukum Edisi Revisi, Prenada Media Group, Jakarta, 2016, hal. 195-196 angkat dan yang relevan dengan objek, dan Studi Lapangan, yaitu dengan melakukan Wawancara kepada narasumber yang berkompeten di bidang yang sesuai dengan objek yang diteliti dan menghimpun data hasil dari wawancara itu disajikan dengan cermat dan akurat supaya mudah dipahami.

\section{Analisis Data}

Suatu analisis yuridis normatif pada hakikatnya menekan pada metode deduktif sebagai pegangan utama, dan metode induktif sebagai tata kerja penunjang. Analisis normatif terutama menggunakan bahan-bahan kepustakaan sebagai sumber penelitiannya. Adapun tahap dari analisis yuridis normatif adalah :

a. Merumuskan asas-asas hukum, baik dari data sosial maupun dari data hukum positif;

b. Merumuskan pengertian-pengertian hukum;

c. pembentukan standar-standar hukum; dan

d. perumusan kaidah-kaidah hukum;

Data yang diperoleh disusun secara sistematis untuk mendapatkan gambaran umum yang jelas mengenai objek penelitian, analisis yang digunakan terhadap data-data yang dipakai dalam penelitian ini adalah Diskriptif Kualitatif, maksudnya data yang diperoleh, disajikan secara diskiptif dan analisis secara kualitatif (content analysis).

\section{PEMBAHASAN}

\section{A. Pertanggungjawaban Kepala Desa Karang Tunggal Kecamatan Tenggarong Seberang Kabupaten Kutai Kartanegara dalam hal pengelolaan keuangan dan aset desa ditinjau dari Undang-Undang}

\footnotetext{
${ }^{7}$ Amiruddin dan Zainal Asikin, Op.cit,
} hal. 32 . 


\section{Republik Indonesia Nomor 6 Tahun 2014 tentang Desa.}

Pada hakikatnya pertanggung jawaban pengelolaan keuangan dan aset desa adalah pelaksanaan tanggungjawab Kepala Desa kepada masyarakat/ rakyat desa atas kewenangan yang dimilikinya dalam hal pengelolaan keuangan dan aset desa untuk kepentingan masyarakat di desa, sebagaimana yang menjadi komitmen politik dan konstitusional dalam UU Desa, bahwa Negara melindungi dan memberdayakan desa agar menjadi kuat, maju, mandiri, dan demokratis sehingga dapat menciptakan landasan yang kokoh dalam melaksanakan pemerintahan dan pembangunan menuju masyarakat yang adil, makmur, dan sejahtera, sehingga rasa tanggungjawab dari Kepala Desa mutlak dalam pengelolaan keuangan dan aset desa. Pemegang kekuasaan pengelolaan keuangan dan aset desa adalah Kepala Desa, yang karena jabatannya mempunyai kewenangan menyelenggarakan keseluruhan pengelolaan keuangan dan aset desa sebagaimana dimaksud Pasal 26 Ayat (2) huruf c UU Desa.

Kepala Desa sebagai kepala pemerintahan desa dan sebagai pemegang kekuasaan pengelolaan keuangan dan aset desa mewakili pemerintah desa, dibantu oleh pelaksana teknis pengelolaan keuangan dan aset desa yang ditunjuk oleh Kepala Desa dari perangkat desa untuk melaksanakan pengelolaan keuangan dan aset desa sebagai unsur penyelenggara pemerintahan desa, atau yang disebut dengan Pelaksana Teknis Pengelolaan Keuangan Desa (PTPKD), yaitu Sekretaris Desa; dan perangkat desa lainnya. Sekretaris Desa berkedudukan selaku koordinator pelaksanaan pengelolaan keuangan dan aset desa, dan juga berperan selaku kuasa penggunaan anggaran/ barang desa dan bertanggung jawab kepada Kepala Desa. Sekretaris Desa membantu Kepala
Desa menyusun kebijakan dan mengkoordinasikan penyelenggaraan urusan pemerintahan desa termasuk pengelolaan keuangan dan aset desa. Dalam hal ini kewenangan pengelolaan keuangan dan aset desa Karang Tunggal ada pada Kepala Desa Karang Tunggal dan sekretaris desa Karang Tunggal bertindak sebagai koordinator, tetapi pertanggungjawaban pelaksanaannya tetap ada pada Kepala Desa Karang Tunggal.

Pengelolaan keuangan dan aset desa sendiri telah diatur mekanisme/ prosedur pengelolaannya dengan peraturan perundang-undangan, yaitu pengelolaan keuangan desa menurut Peraturan Menteri Dalam Negeri Republik Indonesia Nomor 113 Tahun 2014 Tentang Pengelolaan Keuangan Desa, dan pengelolaan aset desa menurut ketentuan Peraturan Menteri Dalam Negeri Republik Indonesia Nomor 1 Tahun 2016 Tentang Pengelolaan Aset Desa.

\section{Pertanggungjawaban Kepala Desa dalam hal Pengelolaan Keuangan Desa Karang Tunggal \\ Pengertian keuangan desa menurut} Pasal 1 Ayat (10) UU Desa adalah semua hak dan kewajiban desa yang dapat dinilai dengan uang serta segala sesuatu berupa uang dan barang yang berhubungan dengan pelaksanaan hak dan kewajiban Desa. Hak dan kewajiban tersebut menimbulkan pendapatan, belanja, dan pembiayaan yang perlu diatur dalam pengelolaan keuangan desa yang baik. Siklus pengelolaan keuangan desa meliputi perencanaan, pelaksanaan, penatausahaan, pelaporan, dan pertanggungjawaban, dengan periodisasi 1 (satu) tahun anggaran, terhitung mulai tanggal 1 Januari sampai dengan 31 Desember setiap tahun berjalan sesuai tahapan yang telah diatur menurut Pasal 1 Ayat (6) Peraturan Menteri Dalam Negeri Republik Indonesia Nomor 113 Tahun 2014 Tentang Pengelolaan Keuangan Desa. 
Keuangan desa Karang Tunggal sendiri yang tetap dan pasti ada untuk setiap tahunnya adalah bersumber dari Dana Desa yang dianggarkan dari Anggaran Pendapatan dan Belanja Negara dan Anggaran Dana Desa dari Pemerintah Kabupaten Kutai Kartanegara. Pengelolaan pemerintah desa Karang Tunggal terhadap sumber keuangan desa Karang Tunggal (Dana Desa dan Anggaran Dana Desa) tersebut dilakukan melalui tahapan-tahapan sebagai berikut:

a. Perencanaan

Perencanaan pengelolaan keuangan desa Karang Tunggal meliputi perencanaan fisik (infrastruktur), belanja pegawai, dan kesejahteraan masyarakat desa Karang Tunggal. Dokumen perencanaan pengelolaan keuangan desa Karang Tunggal antara lain meliputi:

1). Rencana Pembangunan Jangka Menengah Desa (RPJMDesa) Karang Tunggal yang ditetapkan dalam jangka waktu 6 (enam) tahun sesuai masa jabatan Kepala Desa Karang Tunggal terpilih, seperti Rencana Pembangunan Jangka Menengah Desa (RPJMDesa) dari Januari 2017 sampai Desember 2022 yang telah ditetapkan dengan Peraturan Desa Karang Tunggal Nomor 07 Tahun 2016 Tentang Rencana Pembangunan Jangka Menengah Desa Tahun 2017-2022. Rencana Pembangunan Jangka Menengah Desa (RPJMDesa) Karang Tunggal memuat penjabaran visi dan misi Kepala Desa Karang Tunggal terpilih, rencana penyelenggaraan pemerintahan desa, pelaksanaan pembangunan, pembinaan kemasyarakatan, pemberdayaan masyarakat dan arah kebijakan perencanaan pembangunan desa Karang Tunggal yang mengacu pada Rencana Pembangunan Jangka Menengah Daerah (RPJMD) Kabupaten Kutai Kartanegara dengan mempertimbangkan kondisi obyektif desa dan prioritas pembangunan daerah Kabupaten Kutai Kartanegara.

2). Rencana Kerja Pemerintah Desa (RKPDesa) Karang Tunggal yang ditetapkan untuk jangka waktu 1 (satu) tahun sebagai Penjabaran dari Rencana Pembangunan Jangka Menengah Desa (RPJMDesa), seperti Rencana Kerja Pemerintah Desa (RKPDes) Tahun 2017 yang ditetapkan dengan Peraturan Desa Karang Tunggal Nomor 8 Tahun 2016 Tentang Rencana Kerja Pemerintah Desa (RKPDes) Tahun 2017 tanggal 15 Desember 2016 sebagai penjabaran Rencana Pembangunan Jangka Menengah Desa (RPJMDesa) Januari 2017 sampai Desember 2022 untuk tahun 2017.

Rencana Kerja Pemerintah Desa (RKPDesa) ini memuat rencana penyelenggaraan pemerintahan desa misalnya untuk penghasilan aparatur pemerintah desa (seperti penghasilan tetap kepala desa), pelaksanaan pembangunan (seperti semenisasi jalan, pembangunan lapangan sepak bola), pembinaan kemasyarakatan (seperti Pelatihan bola volley, dan Pelaksanaan MTQ), dan pemberdayaan masyarakat desa (seperti Kegiatan PKK, dan Karang taruna). Rencana Kerja Pemerintah Desa (RKPDesa) menjadi dasar menyusun Rencana Anggaran Pendapatan dan Belanja Desa (RAPBDesa) yang akan ditetapkan menjadi Anggaran Pendapatan dan 
Belanja Desa (APBDesa) untuk menjamin kepastian rencana kegiatan, dalam arti mengikat pemerintah desa dan semua pihak yang terkait, untuk melaksanakan kegiatan sesuai rencana yang telah ditetapkan, serta menjamin tersedianya anggaran dalam jumlah yang tertentu untuk melaksanakan kegiatan pemerintah desa Karang Tunggal.

3). Anggaran Pendapatan dan Belanja Desa (APBDesa) Karang Tunggal, seperti Anggaran Pendapatan dan Belanja Desa (APBDesa) Karang Tunggal Tahun 2017 yang ditetapkan dengan Peraturan Desa Karang Tunggal Nomor 9 Tahun 2016 tentang Anggaran Pendapatan dan Belanja Desa Tahun 2017 tanggal 30 Desember 2016 dengan perinciannya yang ditetapkan dengan Peraturan Kepala Desa Karang Tunggal Nomor 3 Tahun 2017 Tentang Penjabaran Anggaran Pendapatan dan Belanja Desa Tahun Anggaran 2017 tanggal 22 Mei 2017.

Rencana Pembangunan Jangka Menengah Desa (RPJMDesa) dan Rencana Kerja Pemerintah Desa (RKPDesa) Karang Tunggal berpedoman kepada perencanaan pembangunan desa dan disusun berdasarkan hasil kesepakatan dalam Musyawarah Perencanaan Pembangunan Desa (Musrenbangdesa) Karang Tunggal yang melibatkan Pemerintah Desa Karang Tunggal, Badan Permusyawaratan Desa Karang Tunggal dan unsur masyarakat desa Karang Tunggal. Dana Desa dan Anggaran Dana Desa serta sumber pendapatan lainnya yang dimiliki desa Karang Tunggal setiap tahun yang disusun dan ditetapkan dalam Anggaran Pendapatan dan Belanja Desa (APBDesa) Karang Tunggal akan digunakan untuk melaksanakan kegiatan Rencana
Kerja Pemerintah Desa (RKPDes) Karang Tunggal setiap tahun berkenaan, seperti Anggaran Pendapatan dan Belanja Desa Tahun Anggaran 2017 yang ditetapkan berdasarkan Peraturan Desa Karang Tunggal Nomor 9 Tahun 2016 berjumlah Rp. 2.100.147.036,- (Dua Miliar seratus juta seratus empat puluh tujuh ribu tiga puluh enam rupiah) untuk membiayai pelaksanaan Rencana Kerja Pemerintah Desa (RKPDesa) Karang Tunggal untuk Tahun 2017 yang ditetapkan berdasarkan Peraturan Desa Karang Tunggal Nomor 8 Tahun 2016 Tentang Rencana Kerja Pemerintah Desa (RKPDes) Tahun 2017 tanggal 15 Desember 2016.

\section{b. Pelaksanaan}

Mekanisme Pelaksanaan pengelolaan keuangan desa dijelaskan menurut ketentuan Pasal 24 s/d Pasal 34 Peraturan Menteri Dalam Negeri Republik Indonesia Nomor 113 Tahun 2014 Tentang Pengelolaan Keuangan Desa. Kepala Desa Karang Tunggal melaksanakan pengelolaan keuangan desa Karang Tunggal yaitu pelaksanaan terhadap Rencana Pembangunan Jangka Menengah Desa (RPJMDesa) yang telah telah dijabarkan dengan Rencana Kerja Pemerintah Desa (RKPDes) yang dibiayai dengan Anggaran Pendapatan dan Belanja Desa (APBDesa) Karang Tunggal yang telah ditetapkan. Pelaksanaan dilakukan setelah pencairan Dana Desa maupun Anggaran Dana Desa sebagai sumber keuangan desa Karang Tunggal dari Pemerintah Kabupaten Kutai Kartanegara, pelaksanaan pencairan Dana Desa tersebut dilakukan dalam 2 (dua) tahap yaitu tahap I (pertama) sebesar $60 \%$ dan tahap 2 (kedua) sebesar $40 \%$, sedangkan untuk Alokasi Dana Desa pencairannya dilakukan dalam 3 (tiga) tahap yaitu tahap I (pertama) sebesar $40 \%$, tahap 2 (kedua) sebesar $30 \%$, dan tahap III (ketiga) sebesar $30 \%$. 
Dana Desa dan Anggaran Dana Desa Karang Tunggal setelah dicairkan Pemerintah Kabupaten Kutai Kartanegara, maka dalam pelaksanaannya akan dilakukan dengan membentuk Tim Pengelola Kegiatan, setiap Tim Pengelola Kegiatan tersebut ditetapkan dengan Keputusan Kepala Desa Karang Tunggal, misalnya Keputusan Kepala Desa Karang Tunggal No.64.02.16.2017/40/KT/SK/I/2017

Tanggal 09 Januari 2017 yang menetapkan Sekretaris Desa Karang Tunggal Bapak Suratmin sebagai koordinator pengelola keuangan desa Karang Tunggal, selanjutnya Tim Pengelola Kegiatan untuk melaksanakan masing-masing kegiatan yang ditetapkan dalam Rencana Kerja Pemerintah Desa (RKPDesa) akan ditetapkan Ketua dan Anggota pelaksananya.

Tim Pengelola Kegiatan ini melaksanakan Rencana Kerja Pemerintah Desa (RKPDesa), dimana dalam pelaksanaannya setiap Ketua Tim Pengelola Kegiatan akan mengajukan Rencana Anggaran Biaya (RAB) untuk melaksanakan kegiatan yang telah ditentukan sebagaimana dimaksud Pasal 27 Peraturan Menteri Dalam Negeri Republik Indonesia Nomor 113 Tahun 2014 Tentang Pengelolaan Keuangan Desa, misalnya Ketua Tim Pengelola Kegiatan semenisasi Jalan mengajukan Rencana Anggaran Biaya (RAB) semenisasi Jalan, dan lain sebagainya sesuai dengan kegiatan yang telah disepakati didalam Rencana Kerja Pemerintah Desa (RKPDesa) Karang Tunggal tahun berkenaan. Menurut Pasal 28 Peraturan Menteri Dalam Negeri Republik Indonesia Nomor 113 Tahun 2014 Tentang Pengelolaan Keuangan Desa, bahwa Rencana Anggaran Biaya (RAB) tersebut menjadi dasar masing-masing Ketua Tim Pengelola Kegiatan untuk mengajukan Surat Permintaan Pembayaran (SPP) atas kegiatan yang dilaksanakan oleh masing-masing Tim Pengelola Kegiatan. c. Penatausahaan

Penatausahaan keuangan desa telah diatur dalam ketentuan Pasal 35 dan Pasal 36 Peraturan Menteri Dalam Negeri Republik Indonesia Nomor 113 Tahun 2014 Tentang Pengelolaan Keuangan Desa, bahwa penatausahaan dilakukan Bendaharan Desa dalam Buku Kas Umum, Buku Kas Pembantu Pajak dan Buku Bank, penatausahaan keuangan desa tersebut selanjutnya akan dipertanggungjawabkan kepada Kepala Desa. Desa Karang Tunggal melakukan penatausahaan keuangan terhadap seluruh transaksi yang ada berupa penerimaan dan pengeluaran keuangan desa Karang Tunggal dilakukan oleh Kepala Urusan Keuangan melalui Bendahara Desa yang dikoordinir oleh Sekretaris Desa, akan tetapi beban tanggungjawabnya tetap ada pada Kepala Desa desa Karang Tunggal, misalnya apabila Bendahara Desa menyampaikan laporan mengenai pemasukan dan pengeluaran keuangan desa dalam satu bulan kepada Kepala Desa, dalam hal ini Kepala Desa harus meneliti/ mengevaluasi kebenaran data-data yang disampaikan Bendahara Desa, karena apabila ada kesalahan-kesalahan yang dikenai pertanggungjawaban adalah Kepala Desa Karang Tunggal sendiri.

Penatausahaan keuangan desa menyangkut seluruh penganggaran yang ada di desa Karang Tunggal yang meliputi 3 (tiga) bagian yaitu:

1). Penatausahaan pendapatan/ penerimaan desa, yaitu pencatatan atau pembukuan semua penerimaan baik yang bersifat tunai maupun yang bersifat transfer (non tunai) yang masuk menjadi keuangan desa Karang Tunggal;

2). Penatausahaan belanja desa, yaitu semua belanja kegiatan yang dikeluarkan oleh Bendahara Desa dibuatkan bukti pengeluaran dan dicatat oleh Bendahara Desa; dan 
3). Penatausahaan pembiayaan desa, yaitu pencatatan atau pembukuan semua realisasi penerimaan pembiayaan maupun pengeluran pembiayaan dengan tujuan agar dapat dilaporkan ke dalam laporan realisasi APBDesa.

Penataausahaan Keuangan Desa

Karang Tunggal yang dilakukan oleh Bendahara Desa atas penerimaan, belanja, dan pembiayaan desa Karang Tunggal tersebut wajib dilaporkan/ dipertanggungjawabkan oleh Bendahara Desa Karang Tunggal melalui laporan pertanggungjawaban yang disampaikan setiap bulan kepada Kepala Desa agar Kepala Desa Karang Tunggal mengetahui dan dapat mengevaluasi administrasi pemasukan dan pengeluaran keuangan desa Karang Tunggal. Penataausahaan Keuangan Desa Karang Tunggal yang dilakukan oleh Bendahara Desa atas penerimaan, belanja, dan pembiayaan desa Karang Tunggal tersebut wajib dilaporkan/ dipertanggungjawabkan oleh Bendahara Desa Karang Tunggal melalui laporan pertanggungjawaban yang disampaikan setiap bulan kepada Kepala Desa agar Kepala Desa Karang Tunggal mengetahui dan dapat mengevaluasi administrasi pemasukan dan pengeluaran keuangan desa Karang Tunggal.

\section{d. Pelaporan dan Pertanggungjawaban}

Berdasarkan Pasal 37 Ayat (1) Peraturan Menteri Dalam Negeri Republik Indonesia Nomor 113 Tahun 2014 Tentang Pengelolaan Keuangan Desa, bahwa Kepala Desa menyampaikan laporan realisasi pelaksanaan APBDesa kepada Bupati/Walikota berupa laporan semester pertama; dan laporan semester akhir tahun, selanjutnya Pasal 38 Ayat (1) mewajibkan Kepala Desa menyampaikan laporan pertanggungjawaban realisasi pelaksanaan APBDesa kepada Bupati/ Walikota setiap akhir tahun anggaran. Pelaksanaan dari tugas, kewenangan, hak, dan kewajiban yang dilakukan oleh Kepala Desa Karang Tunggal selaku kepala pemerintahan di Desa Karang Tunggal dalam pengelolaan keuangan desa, maka kepala desa berkewajiban untuk menyampaikan laporan dan pertanggungjawaban bersifat periodik semesteran dan tahunan, proses Pelaporan dan pertanggungjawaban ini merupakan tahapan terakhir dalam pengelolaan keuangan desa, setelah seluruh kegiatan selesai dilakukan pemerintah desa Karang Tunggal, pemerintah desa Karang Tunggal melalui Sekretaris Desa Karang Tunggal selaku koordinator dalam hal pelaksanaan kegiatan di desa Karang Tunggal menyusun laporan pertanggungjawaban pengelolaan keuangan desa Karang Tunggal untuk dievaluasi dan disetujui oleh Kepala Desa Karang Tunggal.

Laporan pertanggung jawaban pengelolaan keuangan desa tersebut sebelum disampaikan kepada Pemerintah Kabupaten Kutai Kartanegara, diperiksa/ diverifikasi terlebih dahulu oleh pihak Kecamatan Tenggarong Seberang dengan membuat Berita Acaranya dan Surat Pengantar untuk disampaikan kepada Bupati Kutai Kartanegara melalui Badan Pemberdayaan Masyarakat dan Pemerintahan Desa (Bapemas dan Pemdes). Laporan pertanggungjawaban pengelolaan keuangan desa yang disampaikan sebagai laporan semesteran realiasasi penggunaan Dana Desa dan Anggaran Dana Desa terhadap pelaksanaan dari APBDesa Karang Tunggal, yaitu pelaporan Dana Desa Karang Tunggal dilakukan dalam 2 (dua) tahap dan Anggaran Dana Desa Karang Tunggal dilaporkan oleh Kepala Desa dalam 3 (tiga) tahap untuk setiap tahunnya. Dana Desa Karang Tunggal dilaporkan 2 (dua) tahap karena pencairan Dana Desa itu sendiri dilakukan dalam 2 (dua) tahap, setelah Dana Desa tahap pertama selesai dilaksanakan oleh pemerintah desa Karang Tunggal, maka 
penggunaannya harus langsung dilaporkan sebagai syarat untuk dapat mencairkan Dana Desa tahap ke-2 (dua), dan terhadap realisasi penggunaan Dana Desa tahap ke-2 (dua) dilaporkan pada akhir tahun berjalan bersamaan dengan laporan pertanggungjawaban realisasi pelaksanaan Anggaran Pendapatan dan Belanja Desa (APBDesa) Karang Tunggal yang tidak terpisahkan dari laporan penyelenggaraan pemerintahan desa, Kepala Desa juga menyampaikan laporan pertanggung jawaban tersebut kepada Badan Permusyawaratan Desa (BPD) dan masyarakat desa Karang Tunggal.

Laporan pertanggungjawaban realisasi penggunaan dari Anggaran Dana Desa Karang Tunggal yang dilakukan dalam 3 (tiga) tahap mekanismenya sama dengan laporan dan pertanggungjawaban penggunaan Dana Desa, selain daripada itu Kepala Desa Karang Tunggal juga memiliki kewajiban untuk menyampaikan laporan penyelenggaraan pemerintahan desa pada akhir masa jabatan kepada Bupati Kutai Kartanegara setelah masa jabatannya berakhir.

Pertanggungjawaban Kepala Desa Karang Tunggal dalam hal pengelolaan keuangan desa telah terlaksana dan terealisasi dengan baik, secara umum keuangan desa Karang Tunggal dapat diserap dan terealisasi $90 \%$ penggunaannya dengan baik, realisasi pelaksanaan keuangan tersebut dapat dilihat dari data penyerapan penggunaan Anggaran Dana Desa yang dimuat dalam Laporan Realisasi Pelaksanaan Anggaran Dana Desa (ADD) Desa Karang Tunggal Semester Pertama Tahun 2017 bahwa Anggaran Dana Desa tahun 2017 tahap I (pertama) yang dicairkan sebesar Rp. 353.538.103,- (tiga ratus lima puluh tiga juta lima ratus tiga puluh delapan ribu seratus tiga rupiah), dengan dana yang terealisasi sebesar Rp. 350.694.364,- (tiga ratus lima puluh juta enam ratus sembilan puluh empat ribu tiga ratus enam puluh empat rupiah), dan Anggaran Dana Desa yang sisa hanya sebesar Rp. 2.843.739,- (dua juta delapan ratus empat puluh tiga ribu tujuh ratus tiga puluh sembilan rupiah).

Sumber keuangan desa Karang Tunggal yang diperoleh dari Dana Desa dan Anggaran Dana Desa tersebut pengelolaannya paling sedikit $70 \%$ (tujuh puluh perseratus) digunakan untuk mendanai penyelenggaraan pemerintahan desa, pelaksanaan pembangunan desa, pembinaan kemasyarakatan desa, dan pemberdayaan masyarakat desa; dan paling banyak $30 \%$ (tiga puluh perseratus) digunakan untuk penghasilan tetap dan tunjangan Kepala Desa dan perangkat desa; operasional pemerintah desa, tunjangan dan operasional Badan Permusyawaratan Desa; dan Insentif rukun tetangga dan rukun warga. Anggaran Dana Desa lebih dominan digunakan untuk Penyelenggaraan pemerintahan desa, sedangkan penggunaan Dana Desa diprioritaskan untuk membiayai kebutuhan pembangunan dan pemberdayaan masyarakat desa Karang Tunggal. Hal ini dapat dilihat dari Rencana Kerja Pemerintah Desa (RKPDes) dan Anggaran Pendapatan dan Belanja Desa (APBDesa) Karang Tunggal.

\section{Pertanggungjawaban Kepala Desa dalam hal Pengelolaan Aset Desa Karang Tunggal}

UU Desa pada Pasal 77 ayat (1) menyebutkan bahwa pengelolaan kekayaan milik desa dilakukan untuk meningkatkan kesejahteraan dan taraf hidup masyarakat desa serta meningkatkan pendapatan desa. Tahapan Pengelolaan aset desa dilakukan mulai dari kegiatan perencanaan, pengadaan, penggunaan, pemanfaatan, pengamanan, pemeliharaan, penghapusan, pemindahtanganan, penatausahaan, pelaporan, penilaian, pembinaan, pengawasan dan pengendalian aset desa 
sebagaimana yang diatur dalam Pasal 1 Ayat (6) Peraturan Menteri Dalam Negeri Republik Indonesia Nomor 1 Tahun 2016 Tentang Pengelolaan Aset Desa.

Adapun pengelolaan aset desa Karang Tunggal yang dilaksanakan pemerintah desa Karang Tunggal yaitu dengan tahapan sebagai berikut:

\section{a). Perencanaan}

Peraturan Menteri Dalam Negeri Republik Indonesia Nomor 1 Tahun 2016 Tentang Pengelolaan Aset Desa pada Pasal 8 Ayat (1) menyebutkan bahwa perencanaan aset desa dituangkan dalam Rencana Pembangunan Jangka Menengah Desa (RPJMDesa), selanjutnya Ayat (2) menjelaskan perencanaan kebutuhan aset desa untuk kebutuhan 1 (satu) tahun dituangkan dalam Rencana Kerja Pemerintahan Desa (RKPDesa) dan ditetapkan dalam APBDesa setelah memperhatikan ketersediaan aset desa yang ada. Berdasarkan ketentuan Pasal 8 Peraturan Menteri Dalam Negeri Republik Indonesia Nomor 1 Tahun 2016 Tentang Pengelolaan Aset Desa tersebut, maka perencanaan pengelolaan aset desa Karang Tunggal merupakan bagian dari rangkaian pengelolaan keuangan desa dalam tahap perencanaan. Artinya dalam hal perencanaan, baik dalam pengelolaan keuangan maupun pengelolaan aset desa, sama-sama dilakukan dalam Musrenbangdesa Karang Tunggal yang dihadiri oleh seluruh pemerintah desa, Badan Permusyawaratan Desa, tokoh masyarakat dan masyarakat pada umumnya.

Perencanaan aset desa Karang Tunggal ini juga ditetapkan bersama didalam Rencana Pembangunan Jangka Menengah Desa (RPJMDesa), Rencana Kerja Pemerintah Desa (RKPDesa) dan Anggaran Pendapatan dan Belanja (APBDesa) Karang Tunggal tahun berjalan, seperti perencanaan aset desa Karang Tunggal yang telah ditetapkan dalam dokumen perencanaan keuangan desa Karang Tunggal yaitu Rencana Pembangunan Jangka Menengah Desa (RPJMDesa) Karang Tunggal Tahun 20172022, Rencana Kerja Pemerintah Desa (RKPDes) Tahun 2017, dan Anggaran Pendapatan dan Belanja Desa Tahun 2017, dimana perencanaan aset desa Karang Tunggal yang telah ditetapkan didalam perencanaan keuangan desa Karang Tunggal tersebut yaitu pada angka 2 huruf $\mathrm{c}$ dan huruf f Rencana Pembangunan Jangka Menengah Desa (RPJMDesa) Karang Tunggal Tahun 2017-2022 tersebut diatas, bahwa Perencanaan aset desa Karang Tunggal dari tahun 2017 s/d tahun 2022 antara lain:

1). Pembangunan gedung SMP

2). Pembangunan gedung PAUD

3). Pembangunan pagar sekolah

4). Pembangunan TK

5). Pembangunan gedung TK/TPA

6). Pembangunan TK

7). Pengadaan alat sinoman

8). Pengadaan terop dan sound system

9). Pengadaan sound system

10). Pengembangan usaha ekonomi, dan

11). Pembuatan gedung futsal.

b) Pengadaan

Pengadaan aset desa Karang Tunggal dilakukan dengan melaksanakan perencanaan aset desa Karang Tunggal yang telah ditetapkan didalam Rencana Pembangunan Jangka Menengah Desa (RPJMDesa), Rencana Kerja Pemerintah Desa (RKPDesa) dan Anggaran Pendapatan dan Belanja (APBDesa) Karang Tunggal. Sebagian besar barang dan aset desa Karang Tunggal diadakan melalui pembelian atau pengadaan langsung oleh pemerintah desa Karang Tunggal menggunakan Anggaran Pendapatan dan Belanja Desa (APBDesa) Karang Tunggal tersebut.

c) Penggunaan 
Berdasarkan ketentuan Pasal 10 Ayat (1) Peraturan Menteri Dalam Negeri Republik Indonesia Nomor 1 Tahun 2016 Tentang Pengelolaan Aset Desa, bahwa penggunaan aset desa ditetapkan dalam rangka mendukung penyelenggaraan Pemerintahan Desa.

Aset desa Karang Tunggal yang digunakan secara langsung oleh pemerintah desa Karang Tunggal pada dasarnya adalah barang inventaris pada kantor desa Karang Tunggal, seperti : Kantor Desa Karang Tunggal, Gedung Badan Permusyawaratan Desa, Komputer, Laptop, Mesin Fotocopy, dan inventaris desa lainnya yang digunakan untuk penyelenggaraan pemerintahan desa Karang Tunggal.

\section{d) Pemanfaatan}

Pemanfaatan aset desa sebagaimana dimaksud Pasal 11 Ayat (1) dan Ayat (2) Peraturan Menteri Dalam Negeri Republik Indonesia Nomor 1 Tahun 2016 Tentang Pengelolaan Aset Desa, adalah dilaksanakan sepanjang tidak dipergunakan langsung untuk menunjang penyelenggaraan pemerintahan desa, yaitu berupa : sewa, pinjam paka, kerjasama pemanfaatan, dan bangun guna serah atau bangun serah guna.

Pemanfaatan terhadap aset desa Karang Tunggal yang dilakukan pemerintah desa Karang Tunggal misalnya adalah pemanfaatan lahan persawahan milik pemerintah desa Karang Tunggal yang diberikan kepada masyarakat untuk dikelola sendiri dan hasilnya dinikmati sendiri oleh masyarakat desa Karang Tunggal, akan tetapi lahan persawahan itu tetap atas nama pemerintah desa Karang Tunggal dan tidak boleh menjadi milik masyarakat itu sendiri, pemerintah desa Karang Tunggal selalu melakukan pengecekannya mengenai status aset desa Karang Tunggal karena menjadi salah satu bagian dalam laporan pertanggungjawaban yang akan disampaikan Kepala Desa kepada Bupati
Kutai Kartanegara bersamaan dengan laporan pertanggungjawaban pengelolaan keuangan desa Karang Tunggal setiap akhir tahun anggaran.

\section{e) Pengamanan}

Peraturan Menteri Dalam Negeri Republik Indonesia Nomor 1 Tahun 2016 Tentang Pengelolaan Aset Desa pada Pasal 19 Ayat (1), (2), dan Ayat (3) menyebutkan pengamanan aset desa adalah sebagai berikut:

1). Pengamanan aset desa wajib dilakukan oleh Kepala Desa dan Perangkat Desa;

2). Pengamanan aset desa meliputi:

2.1 Pengamanan administrasi antara lain pembukuan, inventarisasi, pelaporan dan penyimpanan dokumen kepemilikan;

2.2 Pengamanan Fisik untuk mencegah terjadinya penurunan fungsi barang, penurunan jumlah barang dan hilangnya barang;

2.3 Pengamanan fisik untuk tanah dan bangunan dilakukan dengan cara pemagaran dan pemasangan tanda batas;

2.4 Selain tanah dan bangunan, pengamanan fisik dilakukan dengan cara penyimpanan dan pemeliharaan; dan

2.5 Pengamanan hukum antara lain dengan melengkapi bukti status kepemilikan.

2.6 Biaya pengamanan aset desa dibebankan pada APBDesa.

Pemerintah desa Karang Tunggal sendiri telah melaksanakan pengamanan terhadap aset yang dimiliki desa Karang Tunggal, baik terhadap aset desa yang bergerak maupun yang tidak bergerak, pengamanan aset desa Karang Tunggal seperti terhadap tanah desa Karang Tunggal yang telah dimintakan pengukurannya kepada Kantor Pertanahan Kabupaten Kutai 
Kartanegara dan disertifikatkan atas nama pemerintah desa Karang Tunggal. Pengamanan aset desa Karang Tunggal lainnya yang dilakukan oleh pemerintah desa Karang Tunggal yaitu setiap tahun pemerintah desa Karang Tunggal selalu melakukan pengecekan dan pencatatan terhadap daftar-daftar aset yang dimiliki desa Karang Tunggal untuk menjadi data aset desa Karang Tunggal pada laporan data Kepala Urusan Umum dan Tata Usaha pemerintahan desa Karang Tunggal.

f) Pemeliharaan

Pemeliharaan aset desa wajib dilakukan oleh Kepala Desa dan perangkat desa, dengan biaya pemeliharaan yang dibebankan pada APBDesa, sebagaimana dimaksud Pasal 20 Ayat (1) Peraturan Menteri Dalam Negeri Republik Indonesia Nomor 1 Tahun 2016 Tentang Pengelolaan Aset Desa. Pemerintah Desa Karang Tunggal melakukan pemeliharaan aset desa Karang Tunggal yaitu terhadap barang inventaris yang sedang dalam unit pemakaian tanpa mengubah, menambah atau mengurangi bentuk maupun konstruksi asalnya, dana anggaran untuk pemeliharaan aset desa Karang Tunggal dianggarkan dalam APBDesa Karang Tunggal setiap tahun berjalan, misalnya untuk perawatan/ pemeliharaan kendaraan, alat-alat elektronik, lapangan bola, lapangan Volly, dan lain sebagainya selalu direncanakan pemeliharaannya didalam Rencana Kerja Pemerintah Desa (RKPDesa) dan dianggarkan setiap tahunnya didalam Anggaran Pendapatan dan Belanja Desa (APBDesa) Karang Tunggal.

Pemeliharaan aset desa Karang Tunggal yang dilakukan oleh pemerintah desa Karang Tunggal untuk tahun 2017 dapat dilihat pada dokumen Rencana Kerja Pemerintah Desa (RKPDesa) Karang Tunggal Tahun 2017 dan Anggaran
Pendapatan dan Belanja Desa (APBDesa) Karang Tunggal Tahun 2017.

\section{g) Penatausahaan}

Penatausahaan aset desa Karang

Tunggal dilakukan oleh Kepala Urusan Umum dan Tata Usaha melalui petugas aset yang dibentuk/ ditetapkan oleh Kepala Desa Karang Tunggal, penatausahaan aset desa yang dilakukan pemerintah desa Karang Tunggal meliputi pembukuan dan inventarisasi terhadap aset desa, Penatausahaan aset desa ini memuat datadata aset desa tentang kategori aset, jumlah aset, tahun perolehan aset, nilai aset, sumber perolehan aset, dan keterangan lainnya yang berhubungan dengan aset desa tersebut sebagaimana data aset desa tahun $2015 \mathrm{~s} / \mathrm{d}$ tahun 2016 sebagai lampiran dalam skripsi ini.

h) Pelaporan

Pelaporan aset desa Karang Tunggal dilakukan bersamaan dengan laporan pertanggungjawaban pelaksanaan APBDesa Karang Tunggal setiap tahun berjalan, salah satu lampiran dari laporan pertanggungjawaban realisasi pelaksanaan APBDesa akhir tahun adalah laporan aset desa Karang Tunggal. Laporan aset desa Karang Tunggal ini mengambarkan akumulasi aset desa Karang Tunggal yang dibuat secara komparatif dengan tahun sebelumnya untuk melihat kenaikan/ penurunannya. Tahapan penghapusan dan pemindahtanganan aset desa belum pernah dilakukan oleh pemerintah desa Karang Tunggal, hal ini disebabkan tidak adanya alasan menghapus/ meniadakan aset desa dari buku data daftar aset desa Karang Tunggal seperti alasan-alasan penghapusan yang diatur dalam Pasal 21 s/d Pasal 24 Peraturan Menteri Dalam Negeri Republik Indonesia Nomor 1 Tahun 2016 Tentang Pengelolaan Aset Desa. Sedangkan tahapan pengelolaan aset desa lainnya yang diatur 
menurut Peraturan Menteri Dalam Negeri Republik Indonesia Nomor 1 Tahun 2016 Tentang Pengelolaan Aset Desa tidak dilakukan oleh pemerintah desa Karang Tunggal karena tahapan pengelolaan itu bukan kewenangan dari pemerintah desa Karang Tunggal, tetapi ada yang menjadi kewenangan dari pemerintah Kabupaten, pemerintah Provinsi dan juga kewenangan dari Kementerian terkait seperti tahapan pengelolaan sebagai berikut:

\section{Penilaian}

Penilaian terhadap aset desa diatur menurut ketentuan Pasal 29 dan Pasal 30 Peraturan Menteri Dalam Negeri Republik Indonesia Nomor 1 Tahun 2016 Tentang Pengelolaan Aset Desa yang menyebutkan:

$\begin{array}{rlr}\text { Pasal 29: } & \text { Pemerintah } & \text { Daerah } \\ & \text { Kabupaten/Kota } & \text { bersama } \\ & \text { Pemerintah Desa melakukan } \\ & \text { inventarisasi dan penilaian } \\ & \text { aset Desa sesuai ketentuan } \\ & \text { peraturan } & \text { perundang- } \\ \text { Pasal 30: } & \text { undangan; } & \text { Penilaian aset desa } \\ & \text { sebagaimana dimaksud dalam } \\ & \text { Pasal 29 dalam rangka } \\ & \text { pemanfaatan } \\ & \text { pemindahtanganan berupa } \\ & \text { tanah dan/atau bangunan } \\ & \text { dilakukan oleh Penilai } \\ & \text { Pemerintah atau Penilai } \\ & \text { Publik. }\end{array}$

2. Pembinaan dan Pengawasan

Pembinaan dan Pengawasan terhadap pengelolaan aset desa menurut Pasal 46 Peraturan Menteri Dalam Negeri Republik Indonesia Nomor 1 Tahun 2016 Tentang Pengelolaan Aset Desa yaitu dilakukan oleh: a. Menteri melalui Direktur Jenderal Bina Pemerintahan Desa melakukan pembinaan dan pengawasan terhadap pelaksanaan pengelolaan aset desa; b. Gubernur melakukan pembinaan dan pengawasan terhadap pelaksanaan pengelolaan aset desa;

c. Bupati/ Walikota melakukan pembinaan dan pengawasan pengelolaan aset desa;

d. Dalam melakukan pembinaan dan pengawasan sebagaimana dimaksud pada ayat (3) Bupati/ Walikota dapat melimpahkan kepada Camat.

Pertanggungjawaban Kepala Desa

Karang Tunggal dalam hal pengelolaan keuangan dan aset desa telah sesuai dengan amanat dan ketentuan UU Desa, pengelolaan keuangan dan aset desa yang dilaksanakan Kepala Desa bersama aparatur pemerintah desa lainnya yang ditunjuk dan ditetapkan oleh Kepala Desa Karang Tunggal telah mencerminkan asas Kepastian Hukum dalam pengelolaan keuangan dan aset desa sebagai Asas-Asas Umum Pemerintahan Yang Baik (AAUPB), yaitu bahwa:

1. Prosedur dan mekanisme pengelolaan keuangan desa yang dilaksanakan pemerintah desa Karang Tunggal telah sesuai dengan tahapan-tahapan pengelolaan keuangan desa yang meliputi tahapan perencanaan, pelaksanaan, penatausahaan, pelaporan dan pertanggungjawaban sebagaimana yang diatur menurut Peraturan Menteri Dalam Negeri Republik Indonesia Nomor 113 Tahun 2014 Tentang Pengelolaan Keuangan Desa, dan

2. Mekanisme pengelolaan aset desa Karang Tunggal yang dilakukan kepala desa Karang Tunggal bersama perangkat desa lainnya hanya meliputi tahapan perencanaan, pengadaan, penggunaan, pemanfaatan, pengamanan, pemeliharaan, penatausahaan, dan pelaporan yang merupakan kewenangan Kepala Desa berdasarkan Peraturan Menteri Dalam Negeri Republik Indonesia Nomor 1 Tahun 2016 Tentang Pengelolaan Aset Desa, sedangkan tahapan penilaian, 
pembinaan dan pengawasan tidak dilaksanakan pemerintah desa Karang Tunggal karena bukan kewenangan dari kepala desa.

Pertanggungjawaban kepala desa Karang Tunggal merupakan tahapan terakhir yang harus dilaksanakan kepala desa Karang Tunggal dalam hal pengelolaan keuangan dan aset desa, yaitu kepala desa Karang Tunggal harus melakukan pertanggungjawaban dari semua aspek pelaksanaan dari kegiatan pengelolaan keuangan dan aset desa, Pertanggungjawaban kepala desa Karang Tunggal tersebut merupakan Laporan Pertanggungjawaban yang disampaikan kepada Bupati dalam hal ini Bupati Kutai Kartanegara melalui Camat yaitu Camat Tenggarong Seberang setiap akhir tahun anggaran paling lambat 1 (satu) bulan setelah akhir tahun anggaran berkenaan. Laporan Pertanggungjawaban kepala desa dalam hal pengelolaan keuangan dan aset desa ditetapkan dengan Peraturan Desa tentang laporan pertanggungjawaban realisasi pelaksanaan APBDesa yang terdiri dari pendapatan, belanja, dan pembiayaan desa, dengan dilampiri:

1). Format laporan pertanggungjawaban realisasi pelaksanaan APBDesa tahun anggaran berkenaan;

2). Format laporan kekayaan milik desa per 31 Desember tahun anggaran berkenaan; dan

3). Format laporan program pemerintah dan pemerintah daerah yang masuk ke desa.

Laporan pertanggungjawaban realisasi pelaksanaan APBDesa merupakan bagian yang tidak terpisahkan dari laporan penyelenggaraan Pemerintahan Desa, disampaikan juga laporan keterangan penyelenggaraan pemerintahan secara tertulis kepada Badan Permusyawaratan Desa setiap akhir tahun anggaran, dan kemudian diinformasikan kepada masyarakat desa secara tertulis dan dengan media informasi yang mudah diakses oleh masyarakat seperti pengumuman, radio komunitas, dan media informasi lainnya. Selain dari Laporan pertanggungjawaban realisasi pelaksanaan APBDesa setiap tahun berjalan Kepala Desa juga harus menyampaikan laporan penyelenggaraan Pemerintahan Desa pada akhir masa jabatan kepada Bupati yaitu kepada Bupati Kutai Kartanegara.

\section{B. Kendala-kendala pertanggung jawaban Kepada Desa Karang Tunggal dalam hal pengelolaan keuangan asset desa}

Kegiatan pengelolaan keuangan desa dan aset desa dapat dilaksanakan dengan baik tentunya harus didukung diantaranya oleh sumber daya manusia yang kompeten dan berkualitas serta sistem dan prosedur pengelolaan yang baik dan memadai. Dalam pengelolaan keuangan dan aset desa tentunya tidak selalu berjalan secara mulus, tetapi ada kendala-kendala yang dihadapi baik kendala dari Internal pelaksana pengelola itu sendiri maupun kendala yang sifatnya datang dari luar (Eksternal).

Adapun kendala-kendala pertanggung jawaban Kepala Desa Karang Tunggal dalam hal pengelolaan keuangan dan aset desa antara lain sebagai berikut:

1. Faktor Internal, yaitu masih rendahnya kapasitas dan personalia perangkat desa dalam penyelenggaraan pemerintahan desa. Mengelola keuangan desa tidak hanya mengandalkan kuasa kepala desa dan perangkatnya. Tetapi butuh keterlibatan berbagai stakeholders yang ada di desa. Apalagi saat ini desa telah mengelola dana dalam jumlah besar. Untuk itu, desa perlu memiliki perangkat desa sebagai unsur penyelenggara pemerintahan desa yang mahir dan 
berkompeten dalam pengelolaan keuangan desa.

\section{Faktor Eksternal}

a. Anggaran seringkali terlambat proses pencairannya dari Pemerintah Kabupaten Kutai Kartanegara

Pencairan anggaran baik Dana Desa maupun Anggaran Dana Desa tidak tepat waktu bahkan ada yang tertunda pencairannya menjadi tahun berikutnya, sehingga perencanaan yang ditetapkan didalam Rencana Kerja Pemerintah Desa (RKPDesa) Karang Tunggal yang dibiayai dengan Anggaran Pendapatan dan Belanja Desa (APBDesa) tahun berjalan tidak terealisasi secara keseluruhan;

b. Birokrasi yang terlalu rumit/ Standar Operasional Prosedur (SOP) terlalu banyak yang harus dilalui;

Pengelolaan keuangan dan aset desa yang dilaksanakan mulai dari tahapan perencanaan sampai tahapan pertanggungjawaban, dalam pelaksanaannya terlalu banyak prosedurnya yang harus dilalui oleh pemerintah desa Karang Tunggal, sehingga terkadang target atau capaian yang diharapkan oleh pemerintah desa untuk jangka waktu tertentu tidak berjalan sesuai harapan.

c. Aturan dan ketentuan atau kebijakan yang selalu berubah-ubah;

Regulasi dalam hal pengelolaan keuangan dan aset desa sendiri yang ditetapkan pemerintah dari tahun ke tahun selalu berubah-ubah, hal ini menyebabkan ketentuan yang telah dilaksanakan pemerintah desa Karang Tunggal tahun sebelumnya berbeda dengan tahun berikutnya, sehingga pemerintah desa harus membuat atau menyusun Standar Operasional yang baru sesuai regulasi baru yang ditetapkan. d. Sering terjadi ketidak sinkronan antara Pihak Pemeriksa dari Inspektorat atau Badan Pemeriksa Keuangan (BPK) dengan Pemerintah Desa selaku pihak penyelenggara; yaitu maksud dan tujuan yang diharapkan oleh pemerintah desa Karang Tunggal untuk kepentingan masyarakat desa Karang Tunggal sering berbeda dengan apa yang diinginkan oleh Pihak Pemeriksa, sehingga pemerintah desa Karang Tunggal harus mengikuti apa yang menjadi masukan dan rekomendasi dari Pihak Pemeriksa, karena kalau tidak dilaksanakan tentunya berdampak kepada realisasi pelaksanaan Rencana Kerja Pemerintah desa.

e. Kendala cuaca yang sering tidak terduga, sehingga pembangunan yang dilaksanakan oleh desa Karang Tunggal yang ditetapkan dalam Rencana Kerja Pemerintah Desa (RKPDesa) Karang Tunggal tahun berkenaan terkadang tidak selesai dilaksanakan dengan tepat waktu.

\section{PENUTUP \\ KESIMPULAN DAN SARAN}

Adapun kesimpulan dalam penelitian ini adalah Pertanggungjawaban Kepala Desa Karang Tunggal dalam hal pengelolaan keuangan dan aset desa disusun dalam bentuk Peraturan Desa tentang laporan pertanggungjawaban realisasi pelaksanaan APBDesa tahun berkenaan, yang terdiri dari pendapatan, belanja, dan pembiayaan dengan melampirkan : format laporan pertanggungjawaban realisasi pelaksanaan APBDesa sebagai bagian yang tidak terpisahkan dari laporan penyelenggaraan pemerintahan desa; format laporan kekayaan milik desa per 31 Desember; dan format laporan program pemerintah dan pemerintah daerah yang masuk ke desa setiap tahun berkenaan dan disampaikan kepada Bupati Kutai Kartanegara melalui Camat 
Tenggarong Seberang paling lambat 1 bulan setelah tahun anggaran berkenaan, laporan keterangan penyelenggaraan pemerintahan secara tertulis kepada Badan Permusyawaratan Desa setiap akhir tahun anggaran dan diinformasikan kepada masyarakat desa karang tunggal secara tertulis dan dengan media informasi yang mudah diakses oleh masyarakat.

Kendala-kendal pertanggungjawaban Kepala Desa Karang Tunggal dalam hal pengelolaan keuangan dan aset desa antara lain: Faktor Internal yaitu masih rendahnya kapasitas dan/ atau personalia perangkat desa dalam penyelenggaraan pemerintahan desa; dan Faktor Eksternal yaitu Anggaran seringkali terlambat proses pencairannya dari Pemerintah Kabupaten Kutai Kartanegara; Birokrasi yang terlalu rumit/ Standar Operasional Prosedur (SOP) terlalu banyak yang harus dilalui; Aturan dan ketentuan atau kebijakan yang selalu berubah-ubah; Sering terjadi ketidak sinkronan antara Pihak Pemeriksa dari Inspektorat atau Badan Pemeriksa Keuangan (BPK) dengan Pemerintah Desa selaku Pihak Penyelenggara; serta Kendala cuaca yang sering tidak terduga.

Adapun saran dalam penelitian ini diharapkan agar pemerintah Kabupaten Kutai Kartanegara/ Dinas terkait untuk dapat kiranya meningkatkan kapasitas aparat/ perangkat desa, khususnya yang berkompeten dalam pengelolaan keuangan dan aset desa, hal ini dapat dilakukan dengan mengadakan seminar, pelatihan, dan pembinaan terhadap aparat/ perangkat desa, dan pengelolaan semua aset desa perlu secara terus menerus diupayakan perbaikan dan peningkatan melalui penataan kelembagaan, penertiban administrasi dan penyusunan pedoman pengelolaan aset-aset desa, yang dilakukan secara simultan, sehingga desa tidak bergantung pada dana transfer dari pemerintah pusat maupun pemerintah daerah.

\section{DAFTAR PUSTAKA}

\section{Buku/ Literatur}

Amiruddin dan Zainal Asikin, Pengantar Metode Penelitian Hukum, PT. Raja Grafindo Persada, Jakarta, Cet. ke-6 Januari 2012.

Arenawati, Administrasi Pemerintahan Daerah, Sejarah, konsep dan penatalaksanaan di Indonesia, Graha Ilmu, Yogjakarta, 2014.

Chabib Soleh dan Heru Rochmansjah, Pengelolaan Keuangan Desa, Fokusmedia, Bandung, 2015.

Dian Bakti Setiawan, Pemberhentian Kepala Daerah: Mekanisme Pemberhentiannya Menurut Sistem Pemerintahan di Indonesia, PT. Raja Grafindo Persada, Jakarta, Cet. I Agustus 2011.

Hanif Nurcholis, Pertumbuhan dan Penyelenggaraan Pemerintahan Desa, Erlangga, Jakarta, 2011.

HAW. Widjaja, Otonomi Desa Merupakan Otonomi Yang Asli, Bulat dan Utuh, PT. Raja Grafindo Persada, Jakarta, Cet. ke-5 Mei 2010.

Mochammad Zaini Mustakim, Kepemimpinan Desa, Kementerian Desa, Pembangunan Daerah Tertinggal, dan Transmigrasi Republik Indonesia, Jakarta Pusat, Cet. I Maret 2015.

M. Silahuddin, Kewenangan Desa Dan Regulasi Desa, Kementerian Desa, Pembangunan Daerah Tertinggal, dan Transmigrasi Republik Indonesia, Jakarta Pusat, Cet. I Maret 2015. 
Peter Mahmud Marzuki, Penelitian Hukum Edisi Revisi, Prenada Media Group, Jakarta, 2016.

Pipin Syarifin dan Dedah Jubaedah, Pemerintah Daerah di Indonesia Dilegkapi Undang-Undang Nomor 32 Tahun 2004, Pustaka Setia, Bandung, 2005.

Riduwan, Metode dan Teknik Penyusunan Proposal Penelitian, Alfabeta, Bandung, Cet. ke-5 Februari 2013.

Suratman dan Philips Dillah, Metode Penelitian Hukum, Alfabeta, Bandung, 2013.

Sutaryono, dkk., Buku Pintar Pengelolaan Aset Desa, Forum Pengembangan Pembaharuan Desa (FPPD), Yogyakarta, Cet. I Februari 2014.

Sutoro Eko, dkk., Desa Membangun Indonesia, Forum Pembaharuan Desa, Yogyakarta, 2014.

Sutoro Eko, Regulasi Baru, Desa Baru, Ide, Misi, dan Semangat UU Desa, Kementerian Desa, Pembangunan Daerah Tertinggal, dan Transmigrasi Republik Indonesia, Jakarta, Cet. I Maret 2015.

Titiek Sri Djatmiati, Maladministrasi dalam Konteks Kesalahan Pribadi dan Kesalahan Jabatan, Tanggung Jawab Pribadi dan Tanggung Jawab Jabatan, dalam Philipus M Hadjon, et, al, Hukum Administrasi dan Good Governance, Universitas Trisakti, Jakarta, 2010.

Tri Widodo W. Utomo, dkk., Pengembangan Kapasitas Pemerintah Desa dan Pengembangan
Pelayanan di Tingkat Desa, Pusat Kajian dan Pendidikan dan Pelatihan Aparatur III Lembaga Administrasi Negara (PKP2A III LAN), Samarinda, 2009.

Zainuddin Ali, Metode Penelitian Hukum, Sinar Grafika, Jakarta, 2009.

\section{Perundang-undangan}

Undang Undang Dasar Tahun 1945 Amandemen IV;

Undang-Undang Republik Indonesia Nomor 6 Tahun 2014 Tentang Desa, Lembaran Negara Republik Indonesia Tahun 2014 Nomor 7, Tambahan Lembaran Negara Republik Indonesia Nomor 5495;

Peraturan Pemerintah Republik Indonesia Nomor 43 Tahun 2014 Tentang Peraturan Pelaksanaan UndangUndang Nomor 6 Tahun 2014 Tentang Desa, Lembaran Negara Republik Indonesia Tahun 2014 Nomor 123, Tambahan Lembaran Negara Republik Indonesia Nomor 5539 ;

Peraturan Pemerintah Republik Indonesia Nomor 47 Tahun 2015 Tentang Perubahan Atas Peraturan Pemerintah Nomor 43 Tahun 2014 Tentang Peraturan Pelaksanaan UndangUndang Nomor 6 Tahun 2014 Tentang Desa, Lembaran Negara Republik Indonesia Tahun 2015 Nomor 157, Tambahan Lembaran Negara Republik Indonesia Nomor 5717 ;

Peraturan Menteri Dalam Negeri Republik Indonesia Nomor 4 Tahun 2007 tentang Pedoman Pengelolaan Kekayaan Desa; 
Peraturan Menteri Dalam Negeri Republik Indonesia Nomor 113 Tahun 2014 Tentang Pengelolaan Keuangan Desa, Berita Negara Republik Indonesia Tahun 2014 Nomor 2093;

Peraturan Menteri Dalam Negeri Republik Indonesia Nomor 1 Tahun 2016 Tentang Pengelolaan Aset Desa, Berita Negara Republik Indonesia Tahun 2016 Nomor 53.

\section{Disertasi}

Tumbur Ompu Sunggu, Disertasi, Keberadaan Komisi Pemberantasan Korupsi Dalam Penegakan Hukum di Indonesia, 2011

\section{Jurnal}

Dewi Risnawati, Pengelolaan Aset Desa Dalam Upaya Meningkatkan Kesejahteraan Di Desa Krayan Bahagia Kecamatan Long Ikis Kabupaten Paser, e-Journal Ilmu Pemerintahan, Volume 5, Nomor 1, 2017: 199-212.

\section{Internet}

http://agunkzzthea.blogspot.co.id/2009/02/p engertian-pemerintahan-desa.html

http://kbbi.web.id/kelola

https://id.wikipedia.org/wiki/Kepaldesa

https://id.wikipedia.org/wiki/Pemerintah_D esa

Periode Maksimal Jabatan Kepala Desa". hukumonline.com/klinik.

http://bppkpd.com/wpcontent/uploads/2016 /12/Permendagri-1-th-2016-ttgPengelolaan-Aset-Desa.pdf. 